\title{
Poczucie „Inności" u osób niewidomych i osób z resztkami wzroku w sferze funkcjonowania psychicznego, fizycznego i emocjonalnego
}

\begin{abstract}
Zaorska Marzenna, The sense of ",being different” that deaf-blind people, and people with weak vision have, in the physical and mental spheres of life [Poczucie "Inności” u osób niewidomych i osób z resztkami wzroku w sferze funkcjonowania psychicznego, fizycznego i emocjonalnego]. Interdyscyplinarne Konteksty Pedagogiki Specjalnej, nr 1, Poznań 2013. Pp. 37-57. Adam Mickiewicz University Press. ISBN 978-83-232-2539-3.
\end{abstract}

The articles main subject are considerations on the topic of the sense of "being different" that young blind, and nearly-blind people feel, in spheres of life such as physical and psychical. The article also highlights the dependencies of the feeling of "being different" on characteristics like age, sex, place of residence, marital status, the state of vision in both the left or the right eye, additional disabilities, other physical limitations, level of disability, period of vision damage, work or educational activity, type of educational activity, acceptance level of the disabled person in his/hers family, personal acceptance of disability, preferred ways of self-improvement, additional rehabilitation needs. Also the hypothetical directions of needed actions are given in the article.

KEY WORDS: disability, sight disability, sight damage, blind person, semi-blind person, education, rehabilitation, mental and physical functioning 


\section{Wprowadzenie}

Problematyka „inności”, a szczególnie kwestie dotyczące obecności poczucia „inności” wśród osób z niepełnosprawnością od pewnego czasu wywołują duże zainteresowanie specjalistów zajmujących się zagadnieniami pedagogiki specjalnej, tak z teoretycznego, jak i praktycznego punktu widzenia. Ponadto celem realizowanych poszukiwań naukowo-praktycznych jest nie tylko określenie obszarów funkcjonowania osoby niepełnosprawnej (gdzie postrzeganie siebie jako „Innego" jest bardzo wyraźne) oraz konkretnych sfer z tym poczuciem związanych, ale również nakreślenie możliwych działań o charakterze profilaktycznym i rehabilitacyjnym. Działania profilaktyczne obejmują zapobieganie możliwym oraz różnorodnym problemom rozwojowym i życiowym osoby niepełnosprawnej, zarówno w kwestii percepcji siebie, własnych możliwości, jak i ewentualnym trudnościom, które mogą być pochodną sposobu postrzegania siebie i konsekwencji ograniczeń wynikających ze stanu niepełnosprawności. Podobne cele przyświecają działaniom rehabilitacyjnym, ale odnoszą się do sytuacji obecności specyficznych problemów natury osobowej, skorelowanych z problemami spowodowanymi niepełnosprawnością; polegają na ich niwelacji i, jeśli to możliwe, przede wszystkim na ich całkowitej redukcji.

Poniżej opisano wyniki zrealizowanych badań empirycznych na temat poczucia „inności” u osób z niepełnosprawnością wzrokową, ze szczególnym uwzględnieniem obszarów funkcjonowania psychicznego i fizycznego.

\section{Opis badań i charakterystyka ogólna osób badanej populacji}

Podstawowym celem badań było określenie obecności poczucia inności wśród osób niewidomych oraz osób z resztkami wzroku (praktycznie niewidomych) $\mathrm{w}$ obszarze funkcjonowania psychicznego i fizycznego. Zostały zrealizowane $\mathrm{w}$ ramach prac nad projektem 
„Wsparcie osób niewidomych na rynku pracy"1. Jego realizatorem był Polski Związek Niewidomych (PZN). Projekt był współfinansowany ze środków Państwowego Funduszu Rehabilitacji Osób Niepełnosprawnych oraz środków Unii Europejskiej (Europejskiego Funduszu Społecznego Kapitał Ludzki). Czas realizacji projektu to kwiecień-grudzień 2009 r. Projekt przygotowano pod adresem osób młodych oraz osób znajdujących się w okresie aktywizacji zawodowej, z poważną (całkowitą i/lub prawie całkowitą) utratą wzroku, które potrzebują specjalistycznej pomocy w planowaniu własnej kariery edukacyjno-zawodowej. Warunkiem włączenia do udziału w projekcie były następujące kryteria: orzeczenie o stopniu niepełnosprawności, kształcenie się w ostatniej klasie szkoły ogólnodostępnej lub integracyjnej na poziomie gimnazjalnym lub ponadgimnazjalnym albo bycie absolwentem tych szkół nie więcej niż do 12 miesięcy od ich ukończeniu, ostrość wzroku mniejsza niż 3/60-0,005 i/lub pole widzenia mniejsze niż 20 stopni, ukończone 16 lat. Każdy uczestnik mógł skorzystać z indywidualnych spotkań z: tyflopedagogiem, psychologiem, lekarzem okulistą, doradcą zawodowym oraz prawnikiem. Zatem był kierowany do udziału w określonych formach rehabilitacji społecznej oraz wybranych szkoleniach, warsztatach i stażach zawodowych ${ }^{2}$.

Badani byli oceniani w kontekście obecności poczucia inności w opinii własnej w sferze funkcjonowania: psychicznego (kryteria: uwaga, pamięć, spostrzegawczość) i fizycznego (kryteria: sprawność ruchowa ogólna, szybkość i precyzja ruchów, koordynacja ruchowa, sprawność manualna). Ocena była dokonywana w czasie realizacji badania tyflopedagogicznego, realizowanego jako jeden z elementów omawianego projektu, i stanowiła element dodatkowy, uzupełniający dane badanie, $\mathrm{z}$ zamiarem przeprowadzenia analiz naukowych pokazujących obecność i odczuwanie "inności” przez badanych w wybranych sferach ich funkcjonowania. W czasie realizacji badań naukowych wykorzystano metodę sondażu dia-

${ }^{1}$ M. Zaorska, Wsparcie osób niewidomych na rynku pracy - refleksje z realizacji pierwszego etapu, [w:] D. Baczała, J.J. Błeszyński, M. Zaorska (red.), Osoba z niepetnosprawnościq - opieka-terapia-wsparcie, Wyd. UMK, Toruń 2009, s. 359-406.

$2<$ www.pzn.org.pl, 28.07.2010>. 
gnostycznego oraz technikę wywiadu swobodnego kierowanego. Natomiast uzyskane wyniki poddano opracowaniu uwzględniającemu jedynie korelaty odsetkowe. Zrezygnowano $\mathrm{z}$ zastosowania współczynnika korelacji, bowiem dla ewentualnych odbiorców zainteresowanych tematyką badań, z grupy osób z niepełnosprawnością wzrokową, byłby on mało zrozumiały i mało czytelny.

Przeanalizowano informacje uzyskane od 45 osób (100\%), w od tym 21 mężczyzn (47\%) i 24 kobiet (53\%); w wieku od 16 do 19 lat było 14 badanych (31\%), powyżej 19 do 26 lat - 15 (33\%), powyżej 26 do 35 lat - 8 (18\%), powyżej 35 do 45 lat - $3(7 \%)$, powyżej 45 do 55 lat - również $3(7 \%)$, powyżej 55 do 64 lat 2 (4\%). 12 respondentów $(27 \%)$ zamieszkiwało duże miasto, 10 (22\%) średnie, $11(24 \%)$ miasto, a $12(27 \%)$ wieś. Z rodziną własną mieszkało 12 osób $(27 \%)$, $\mathrm{z}$ rodziną pochodzenia $-31(69 \%)$, samotnie -2 osoby $(4 \%)$.

Stan wzroku badanych w oku prawym był następujący: (a) całkowite niewidzenie - 12 osób (27\%), poczucie światła - 1 osoba (2\%), więcej niż poczucie światła - 32 osoby (71\%). W oku lewym zaś: całkowite niewidzenie - 10 osób (22\%), poczucie światła 1 osoba ( $2 \%)$, więcej niż poczucie światła - 34 osoby (76\%). 8 osób (18\%) miało inne niepełnosprawności (dysfunkcje narządu ruchu, niepełnosprawność intelektualna), a 12 (27\%) inne ograniczenia dotyczące stanu zdrowia (np. schorzenia układu krążenia, kręgosłupa, schorzenia endokrynologiczne, alergie).

Orzeczony umiarkowany stopień niepełnosprawności miało 35 badanych $(78 \%)$. Pozostali byli w trakcie orzekania o stopniu niepełnosprawności. 28 badanych (62\%) miało uszkodzenie wzroku od urodzenia, $6(13,5 \%)$ nabyło wadę wzroku w okresie wczesnego dzieciństwa, $6(13,5 \%)$ w okresie średniego lub późnego dzieciństwa, 5 (11\%) w okresie dorosłości. Czynniki dziedziczne były przyczyną problemów wzrokowych u 10 badanych (22\%), wrodzone $23(51,5 \%)$, zaćma u 1 osoby (2\%), nowotwory narządu wzroku lub mózgu u 6 osób (13,5\%), urazy u 4 (9\%), inne u 1 osoby (2\%).

W badanej grupie było 11 zamężnych/żonatych (24\%), 33 kawalerów/panien (74\%), 1 osoba (2\%) w związku konkubenckim. Pracowało i równocześnie uczyło się 4 badanych (9\%), pracowało i nie uczyło się 3 (7\%), nie pracowało i nie uczyło się 17 (33\%), uczyło się 
17 - 33\% (szkoła gimnazjalna, średnia, policealna), studiowało 8 - 18\% (fizjoterapię, pedagogikę rodziny, pedagogikę resocjalizacyjną).

Wyłącznie w systemie szkolnictwa ogólnodostępnego kształciło się 29 respondentów (64\%), wyłącznie w systemie szkolnictwa specjalnego 2 (4\%), wyłącznie w systemie szkolnictwa integracyjnego $5(11 \%)$, w szkolnictwie ogólnodostępnym, a zatem specjalnym $7(17 \%)$, w systemie szkolnictwa integracyjnego, a następnie specjalnego 1 (2\%), szkolnictwa specjalnego, a kolejno ogólnodostępnego $1(2 \%)$. Akceptację stanu swojej niepełnosprawności w rodzinie pochodzenia zdeklarowało 39 badanych (87\%), natomiast własną akceptację niepełnosprawności wzrokowej 31 (69\%); brak takiej akceptacji odnotowano u 14 badanych (31\%).

$\mathrm{Z}$ proponowanych, w ramach projektu, form doskonalenia zawodowego: 35 badanych (78\%) podało chęć uczestnictwa w szkoleniu komputerowym, 22 (49\%) w szkoleniu z zakresu obsługi biura i recepcji, 1 osoba (2\%) w innym szkoleniu - masaż kamieniami. Żaden nie wybrał szkolenia z obsługi klienta telefonicznego. 7 osób (17\%) zostało skierowanych na dodatkowe zajęcia z czynności dnia codziennego, 7 (17\%) z technik komunikacji, 9 (20\%) z usprawniania widzenia oraz doboru pomocy optycznych i nieoptycznych, $12(27 \%)$ $\mathrm{z}$ orientacji przestrzennej i przemieszczania w przestrzeni, 14 (31\%) z rehabilitacji psychologicznej, 15 (33\%) z budowania własnego wizerunku, 1 (2\%) na dodatkowe zajęcia tyflopedagogiczne. Wszystkie osoby $(100 \%)$ włączono w warsztaty aktywizacji zawodowej realizowane na terenie Okręgu PZN.

\section{Wyniki badania obecności poczucia inności u osób niewidomych oraz osób z resztkami wzroku w obszarze funkcjonowania psychicznego i fizycznego}

Badana grupa była pytana o obecność poczuci inności w wybranych obszarach funkcjonowania. Uzyskane wyniki podano w tabeli.

Z przedstawionych danych można wnioskować, że badani mają poczucie bycia „Innym” w sferze funkcjonowania psychicznego. 
W kwestii uwagi poczucie inności obecne było u 31 osób (69\%), pamięci u $23(51 \%)$, spostrzegawczości zaś u 33 (73\%). W obszarze funkcjonowania fizycznego natomiast była następująca: sprawność ruchowa ogólna 29 osób (64\%), szybkość i precyzja ruchów 30 (67\%), koordynacja ruchowa 29 (64\%), sprawność manualna 32 (71\%).

Tabela. Poczucie inności u osób niewidomych i osób z resztkami wzroku w obszarze funkcjonowania psychicznego i fizycznego

\begin{tabular}{|l|c|c|c|c|}
\hline \multirow{2}{*}{ Obszar funkcjonowania i jego kryteria } & \multicolumn{2}{|c|}{$\begin{array}{c}\text { Obecność poczucia } \\
\text { inności }\end{array}$} & \multicolumn{2}{c|}{$\begin{array}{c}\text { Brak poczucia } \\
\text { inności }\end{array}$} \\
\cline { 2 - 5 } & $N$ & {$[\%]$} & $N$ & {$[\%]$} \\
\hline \multicolumn{5}{|c|}{ Obszar funkcjonowania psychicznego } \\
\hline Uwaga & 31 & 69 & 14 & 31 \\
\hline Pamięć & 23 & 51 & 22 & 49 \\
\hline Spostrzegawczość & 33 & 73 & 12 & 26 \\
\hline \multicolumn{5}{|c|}{ Obszar funkcjonowania fizycznego } \\
\hline Sprawność ruchowa ogólna & 29 & 64 & 16 & 36 \\
\hline Szybkość i precyzja ruchów & 30 & 67 & 15 & 33 \\
\hline Koordynacja ruchowa & 29 & 64 & 16 & 36 \\
\hline Sprawność manualna & 32 & 71 & 13 & 29 \\
\hline
\end{tabular}

W wykonanych badaniach empirycznych obecność poczucia inności w wybranych obszarach funkcjonowania skorelowano z wybranymi zmiennymi odniesionymi do określonych cech osobistych oraz cech wynikających z faktu uszkodzenia wzroku: wiek, płeć, sposób zamieszkiwania, stan cywilny, stan wzroku w oku prawym i lewym, dodatkowe niepełnosprawności, inne ograniczenia związane ze stanem zdrowia, stopień niepełnosprawności, okres uszkodzenia wzroku, przyczyna uszkodzenia wzroku, aktywność edukacyjna i zawodowa, typ realizowanej/zrealizowanej edukacji, akceptacja niepełnosprawności w rodzinie, akceptacja niepełnosprawności własna, preferowane formy doskonalenia zawodowego, dodatkowe potrzeby rehabilitacyjne. 


\section{Obszar funkcjonowania psychicznego - wyniki}

Podczas badań w obszarze funkcjonowania psychicznego uzyskano następujące wyniki:

1. Wiek: (a) uwaga - w grupie wiekowej do 19. roku życia poczucie inności obecne było u 10 osób (22\%); powyżej 19 do 26 lat u 11 (25\%); powyżej 26. do 35. roku życia u 6 (13\%); powyżej 35 do 45 lat u 2 (4\%); powyżej 45 do 55 lat także u 2 (2\%); powyżej 55 do 64 lat - brak poczucia inności - w grupie tej były tylko 2 osoby (4\%); (b) pamięć - w grupie wiekowej do 19. roku życia poczucie inności obecne było u 11 osób (25\%); powyżej 19 do 26 lat u 5 (11\%); powyżej 26. do 35. roku życia u 3 (7\%); powyżej 35 do 45 lat - również u $3(7 \%)$; powyżej 45 do 55 lat - brak poczucia inności; powyżej 55 do 64 lat - u 1 osoby (2\%); (c) spostrzegawczość - w grupie wiekowej do 19. roku życia poczucie inności obecne było u 12 osób (26\%); powyżej 19 do 26 lat u 12 (26\%); powyżej 26. do 35. roku życia u 6 (13\%); powyżej 35 do 45 lat - u 1 osoby (2\%); powyżej 45 do 55 lat u 1 osoby (2\%); powyżej 55 do 64 lat także u 1 osoby (2\%).

2. Płeć - mężczyźni: (a) uwaga - poczucie inności u 14 osób (31\%); (b) pamięć u 13 (29\%); (c) spostrzegawczość u 16 (36\%); kobiety: (a) uwaga - poczucie inności u 17 osób (38\%); (b) pamięć u $10(22 \%)$; (c) spostrzegawczość u 17 kobiet (38\%).

3. Miejsce zamieszkania: (a) uwaga: poczucie inności u badanych mieszkających w większych miastach - 6 osób (13\%); średnich miastach - 7 (15\%); małych miastach - 8 (18\%); na wsi - $10(22 \%)$; (b) pamięć: poczucie inności u badanych mieszkających w większych miastach -4 osoby (9\%); średnich miastach - także 4 osoby (9\%); małych miastach - 7 (15\%); na wsi - 8 (18\%); (c) spostrzegawczość: poczucie inności u badanych mieszkających w większych miastach - 5 osób (11\%); średnich miastach - 8 (18\%); małych miastach - $10(22 \%)$; na wsi - 10 (22\%).

4. Sposób zamieszkiwania: (a) uwaga - poczucie inności u osób mieszkających z rodziną własną -4 osoby ( $9 \%$ ); z rodzicem/rodzicami - 26 osób (58\%); samotnie - 1 osoba (2\%); (b) pamięć - poczucie inności u mieszkających z rodziną własną - 7 osób (15\%); z rodzicem/rodzi- 
cami - 14 (31\%); samotnie - 2 osoby (4\%); (c) spostrzegawczość - poczucie inności u osób mieszkających z rodziną własną - 10 osób (22\%); z rodzicem/rodzicami - 21 (47\%); samotnie - 2 osoby (4\%).

5. Stan cywilny: (a) uwaga - zamężni/mężatki - 7 osób z poczuciem inności (15\%); kawalerowie/panny - 23 osoby (23\%); w związku konkubenckim 1 osoba (2\%); (b) pamięć - zamężni/mężatki 1 osoba $(2 \%)$ z poczuciem inności; kawalerowie/panny - 21 osób (47\%); w związku konkubenckim 1 osoba (2\%); (c) spostrzegawczość - zamężni/mężatki - 9 osób (20\%) z poczuciem inności; kawalerowie/panny - 23 (51\%); w związku konkubenckim 1 osoba (2\%).

6. Stan wzroku w oku prawym: (a) uwaga - poczucie inności u badanych z całkowitym niewidzeniem - 11 osób (25\%); z poczuciem światła - 1 osoba ( $2 \%)$; z więcej niż poczucie światła - 20 osób (44\%); (b) pamięć - z całkowitym niewidzeniem - 10 osób (22\%); z poczuciem światła - 1 osoba (2\%); z więcej niż poczucie światła 13 osób (29\%); (c) spostrzegawczość - z całkowitym niewidzeniem 10 osób (22\%); z poczuciem światła - 1 osoba ( $2 \%)$; z więcej niż poczucie światła - 23 osoby (51\%).

7. Stan wzroku w oku lewym: (a) uwaga - poczucie inności u badanych z całkowitym niewidzeniem - 9 osób (20\%); z poczuciem światła - 1 (2\%); z więcej niż poczucie światła - 22 (49\%); (b) pamięć - z całkowitym niewidzeniem - 9 osób (20\%); z poczuciem światła - 1 osoba ( $2 \%)$; z więcej niż poczucie światła - 24 osoby (53\%); (c) spostrzegawczość - z całkowitym niewidzeniem - 9 osób (20\%); z poczuciem światła - brak osoby z poczuciem inności; z więcej niż poczucie światła - 24 osoby (53\%).

8. Dodatkowe niepełnosprawności: (a) uwaga - poczucie inności $\mathrm{u}$ badanych $\mathrm{z}$ brakiem dodatkowych niepełnosprawności - 24 osoby (53\%); u badanych z obecnymi dodatkowymi niepełnosprawnościami - 9 (20\%); (b) pamięć - poczucie inności u badanych z brakiem dodatkowych niepełnosprawności - 17 osób (38\%); u badanych z obecnymi dodatkowymi niepełnosprawnościami - 7 (15\%); (c) spostrzegawczość - poczucie inności u badanych z brakiem dodatkowych niepełnosprawności - 26 osób (58\%); u badanych z obecnymi dodatkowymi niepełnosprawnościami - 7 (15\%). 
9. Inne ograniczenia związane ze stanem zdrowia: (a) uwaga - poczucie inności u badanych z brakiem dodatkowych ograniczeń zdrowotnych - 22 osoby (49\%); u badanych z obecnymi dodatkowymi problemami zdrowotnymi - 9 (20\%); (b) pamięć - poczucie inności $\mathrm{u}$ badanych $\mathrm{z}$ brakiem dodatkowych ograniczeń zdrowotnych - 12 osób (26\%); u badanych z obecnymi dodatkowymi problemami ze zdrowiem - 11 osób (25\%); (c) spostrzegawczość - poczucie inności $\mathrm{u}$ badanych $\mathrm{z}$ brakiem dodatkowych problemów zdrowotnych - 22 osoby (49\%); u badanych z obecnymi dodatkowymi problemami zdrowotnymi - 11 (25\%).

10. Stopień niepełnosprawności: (a) uwaga - poczucie inności $\mathrm{u}$ badanych $\mathrm{z}$ umiarkowanym stopniem niepełnosprawności 22 osoby (49\%); u badanych znajdujących się w trakcie orzecznictwa - 9 osób (20\%); (b) pamięć - z umiarkowanym stopniem niepełnosprawności - 14 osób (31\%); u badanych znajdujących się w trakcie orzecznictwa - 10 (22\%); (c) spostrzegawczość - z umiarkowanym stopniem niepełnosprawności - 23 osoby (51\%); znajdujący się w trakcie orzecznictwa - 10 osób (22\%).

11. Okres uszkodzenia wzroku: (a) uwaga - poczucie inności u badanych z uszkodzeniem wzroku od urodzenia - 19 osób (42\%); od wczesnego dzieciństwa - 5 (11\%); od okresu średniego lub późnego dzieciństwa - również 5 (11\%); od okresu młodzieńczego lub dorosłości - 2 osoby (4\%); (b) pamięć - u badanych z uszkodzeniem wzroku od urodzenia - 19 osób (42\%); od wczesnego dzieciństwa 4 osoby (9\%); od okresu średniego lub późnego dzieciństwa 5 osób (11\%); od okresu młodzieńczego lub dorosłości - 2 osoby (4\%); (c) spostrzegawczość - z uszkodzeniem wzroku od urodzenia - 19 osób (42\%); od wczesnego dzieciństwa - 5 (11\%); od okresu średniego lub późnego dzieciństwa - 6 osób (13\%); od okresu młodzieńczego lub dorosłości - 3 (7\%).

12. Przyczyna uszkodzenia wzroku: (a) uwaga - poczucie inności u badanych z uszkodzeniem wzroku na tle czynników dziedzicznych - 5 osób (11\%); na tle czynników wrodzonych - 18 (40\%); zaćmy - brak osoby z poczuciem inności; nowotworów oka lub mózgu - 6 (13\%); urazów - 2 osoby (4\%); innych czynników - brak 
osoby z poczuciem inności; (b) pamięć - z uszkodzeniem wzroku na tle czynników dziedzicznych - 5 osób (11\%); na tle czynników wrodzonych - 12 (26\%); zaćmy - brak osoby z poczuciem inności; nowotworów oka lub mózgu - 5 (11\%); urazów - 1 osoba (2\%); innych czynników - brak osoby z poczuciem inności; (c) spostrzegawczość - z uszkodzeniem wzroku na tle czynników dziedzicznych - 8 osób (18\%); na tle czynników wrodzonych - 16 (36\%); zaćmy - brak osoby z poczuciem inności; nowotworów oka lub mózgu - 6 (13\%); urazów - 3 osoby (7\%); innych czynników - brak osoby z poczuciem inności.

13. Aktywność edukacyjna i/lub zawodowa: (a) uwaga - poczucie inności u badanych pracujących i równocześnie uczących się - 3 osoby (7\%); pracujących i nie uczących się - także 3 (7\%); nie pracujących i nie uczących się - 13 osób (29\%); uczących się (szkoła gimnazjalna, średnia, policealna) - 8 (18\%); studiujących - 4 (9\%); (b) pamięć - u badanych pracujących i równocześnie uczących się 2 osoby (4\%); pracujących i nie uczących się - 1 osoba ( $2 \%)$; nie pracujących i nie uczących się - 10 osób (22\%); uczących się (szkoła gimnazjalna, średnia, policealna) - 10 (22\%); studiujących - brak osób z poczuciem inności; (c) spostrzegawczość - u badanych pracujących i równocześnie uczących się - 3 osoby (7\%); pracujących i nie uczących się - również 3 (7\%); nie pracujących i nie uczących się - 12 osób (26\%); uczących się (szkoła gimnazjalna, średnia, policealna) - 11 (25\%); studiujących - 4 osoby (9\%).

14. Typ realizowanej/zrealizowanej edukacji: (a) uwaga - poczucie inności u badanych edukujących się wyłącznie w szkole ogólnodostępnej - 18 osób (40\%); wyłącznie w szkole specjalnej 2 osoby (4\%); wyłącznie w szkole integracyjnej - 4 (4\%); w szkole ogólnodostępnej, a zatem specjalnej - 5 (11\%); w szkole integracyjnej, a zatem specjalnej - 1 osoba ( $2 \%)$; w szkole specjalnej, a następnie ogólnodostępnej - 1 osoba (2\%); (b) pamięć - u badanych edukujących się wyłącznie w szkole ogólnodostępnej - 17 osób (38\%); wyłącznie w szkole specjalnej - 2 osoby (4\%); wyłącznie w szkole integracyjnej - 1 osoba (2\%); w szkole ogólnodostępnej, a zatem specjalnej - 2 osoby (4\%); w szkole integracyjnej, a kolejno specjalnej 
- 1 osoba (2\%); w szkole specjalnej, a następnie ogólnodostępnej - brak osoby z poczuciem inności; (c) spostrzegawczość - u badanych edukujących się wyłącznie w szkole ogólnodostępnej - 20 osób (44\%); wyłącznie w szkole specjalnej - 2 osoby (4\%); wyłącznie w szkole integracyjnej - 3 (7\%); w szkole ogólnodostępnej, a kolejno specjalnej - 6 (13\%); w szkole integracyjnej, a następnie specjalnej 1 osoba (2\%); w szkole specjalnej, a zatem ogólnodostępnej - 1 osoba $(2 \%)$.

15. Akceptacja niepełnosprawności w rodzinie: (a) uwaga - poczucie inności u badanych z akceptacją swojej niepełnosprawności w rodzinie - 26 osób (58\%); z brakiem akceptacji swojej niepełnosprawności w rodzinie - 5 (11\%); (b) pamięć - u mających akceptację swojej niepełnosprawności w rodzinie - 11 osób (25\%); nie mających akceptacji swojej niepełnosprawności w rodzinie - $12(26 \%)$; (c) spostrzegawczość - u mających akceptację swojej niepełnosprawności w rodzinie - 27 osób (60\%); nie mających akceptacji swojej niepełnosprawności w rodzinie - 6 (13\%).

16. Akceptacja niepełnosprawności własna: (a) uwaga - poczucie inności u badanych akceptujących swoją niepełnosprawność - 19 osób (42\%); u nie akceptujących swojej niepełnosprawności - 12 (26\%); (b) pamięć - u akceptujących swoją niepełnosprawność - 11 (25\%); u nie akceptujących swojej niepełnosprawności - 12 (26\%); (c) spostrzegawczość - u akceptujących swoją niepełnosprawność - 21 osób (47\%); u nie akceptujących swojej niepełnosprawności - 12 (26\%).

17. Preferowane formy doskonalenia zawodowego: (a) uwaga - poczucie inności u badanych preferujących szkolenie komputerowe - 21 osób (47\%); szkolenie z obsługi biura i recepcji - 13 (29\%); szkolenie z masażu kamieniami - 1 osoba (2\%); (b) pamięć - u preferujących szkolenie komputerowe - 14 osób (31\%); szkolenie z obsługi biura i recepcji - 9 (20\%); szkolenie z masażu kamieniami - 1 osoba $(2 \%)$ z brakiem poczucia inności; (c) spostrzegawczość - u preferujących szkolenie komputerowe - 28 osób (62\%); szkolenie z obsługi biura i recepcji - 15 (33\%); szkolenie z masażu kamieniami - 1 osoba (2\%).

18. Dodatkowe potrzeby rehabilitacyjne: (a) uwaga - poczucie inności u badanych wymagających dodatkowych zajęć specjali- 
stycznych z czynności dnia codziennego - 7 osób (15\%); z technik komunikacji - 5 (11\%); z usprawniania widzenia oraz doboru pomocy optycznych i nieoptycznych - 4 (9\%); z orientacji przestrzennej i przemieszczania się $\mathrm{w}$ przestrzeni - 10 (22\%); z rehabilitacji psychologicznej - 11 (25\%); z budowania własnego wizerunku także 11 (25\%); innych (konsultacja tyflopedagogiczna) - 1 osoba (2\%); (b) pamięć - u wymagających dodatkowych zajęć specjalistycznych z czynności dnia codziennego - 6 osób (13\%); z technik komunikacji - 4 (9\%); z usprawniania widzenia oraz doboru pomocy optycznych i nieoptycznych - również 4 (9\%); z orientacji przestrzennej i przemieszczania się w przestrzeni - $9(20 \%)$; z rehabilitacji psychologicznej - 11 (25\%); z budowania własnego wizerunku - 5 osób (11\%); innych (konsultacja tyflopedagogiczna) - 1 osoba (2\%); (c) spostrzegawczość - u wymagających dodatkowych zajęć specjalistycznych z czynności dnia codziennego - 7 osób (18\%); z technik komunikacji - 6 (13\%); z usprawniania widzenia oraz doboru pomocy optycznych i nieoptycznych $-8(18 \%)$; z orientacji przestrzennej i przemieszczania się w przestrzeni - 11 (25\%); z rehabilitacji psychologicznej - 12 (26\%); z budowania własnego wizerunku - 14 (31\%); innych (konsultacja tyflopedagogiczna) - 1 osoba (2\%).

$\mathrm{W}$ obszarze funkcjonowania fizycznego otrzymano poniższe rezultaty:

1. Wiek: (a) ogólna sprawność ruchowa - poczucie inności w grupie wiekowej do 19. roku życia - 9 osób (20\%); powyżej 19 do 26 lat - 8 (18\%); powyżej 26. do 35. roku życia - 4 (9\%); powyżej 35 do 45 lat - 3 (7\%); powyżej 45 do 55 lat także 3 (7\%); powyżej 55 do 64 lat - 2 (4\%); (b) szybkość i precyzja ruchów - w grupie wiekowej do 19. roku życia - 9 osób (20\%); powyżej 19 do 26 lat - 9 (20\%); powyżej 26. do 35. roku życia - 4 (9\%); powyżej 35 do 45 lat 3 (7\%); powyżej 45 do 55 lat - 3 (7\%); powyżej 55 do 64 lat - 2 (4\%); (c) koordynacja ruchowa - w grupie wiekowej do 19. roku życia 9 (20\%); powyżej 19 do 26 lat - 9 (20\%); powyżej 26. do 35. roku życia - 3 (7\%); powyżej 35 do 45 lat - 3 (7\%); powyżej 45 do 55 lat - również 3 (7\%); powyżej 55 do 64 lat - 2 (4\%); (d) sprawność manualna - w grupie wiekowej do 19. roku życia - 10 osób (22\%); powyżej 19 
do 26 lat - 9 (20\%); powyżej 26. do 35. roku życia - 5 (11\%); powyżej 35 do 45 lat - 3 (7\%); powyżej 45 do 55 lat również 3 (7\%); powyżej 55 do 64 lat $-2(4 \%)$.

2. Płeć - mężczyźni: (a) ogólna sprawność ruchowa - poczucie inności obecne u 10 osób (22\%); (b) szybkość i precyzja ruchów poczucie inności u 12 (26\%); (c) koordynacja ruchowa - u 11 (25\%); (d) sprawność manualna - u 15 (33\%); kobiety: (a) ogólna sprawność ruchowa - poczucie inności u 19 (42\%); (b) szybkość i precyzja ruchów - u 18 (40\%); (c) koordynacja ruchowa - u 18 (40\%); (d) sprawność manualna - u 17 kobiet (38\%).

3. Miejsce zamieszkania: (a) ogólna sprawność ruchowa - poczucie inności u badanych mieszkających w większych miastach 7 (15\%); średnich miastach - 7 (15\%); małych miastach - 6 (13\%); na wsi - 9 (20\%); (b) szybkość i precyzja ruchów - poczucie inności $\mathrm{u}$ badanych mieszkających w większych miastach - 7 (15\%); średnich miastach - 8 (18\%); małych miastach - 6 (13\%); na wsi 9 (20\%); (c) koordynacja ruchowa - poczucie inności u badanych mieszkających w większych miastach - $6(13 \%)$; średnich miastach 7 (15\%); małych miastach - także 7 (15\%); na wsi - 3 (7\%); (d) sprawność manualna - poczucie inności u badanych mieszkających $\mathrm{w}$ większych miastach - 8 (18\%); średnich miastach - 7 (15\%); małych miastach - $9(20 \%)$; na wsi - $8(18 \%)$.

4. Sposób zamieszkiwania: (a) sprawność ruchowa ogólna - poczucie inności u osób mieszkających z rodziną własną - 10 (22\%); z rodzicem/rodzicami - 17 (38\%); samotnie - 2 (4\%); (b) szybkość i precyzja ruchów - poczucie inności u osób mieszkających z rodziną własną - 10 (22\%); z rodzicem/rodzicami - 18 (40\%); samotnie 2 (4\%); (c) koordynacja ruchowa - poczucie inności u osób mieszkających z rodziną własną - 10 (22\%); z rodzicem/rodzicami - 17 (38\%); samotnie - 2 (4\%); (d) sprawność manualna - poczucie inności u osób mieszkających z rodziną własną - 10 (22\%); z rodzicem/rodzicami - 20 (44\%); samotnie - 2 (4\%).

5. Stan cywilny: (a) ogólna sprawność ruchowa - zamężni/mężatki - 10 osób (22\%) z poczuciem inności; kawalerowie/panny - 18 (40\%); w związku konkubenckim 1 osoba (2\%); (b) szybkość i pre- 
cyzja ruchów - zamężni/mężatki - 10 osób (22\%); kawalerowie/panny - 19 (42\%); w związku konkubenckim 1 osoba (2\%); (c) koordynacja ruchowa - zamężni/mężatki - 10 osób (22\%); kawalerowie/panny 18 (40\%); w związku konkubenckim 1 osoba (2\%); (d) sprawność manualna - zamężni/mężatki - 9 osób (20\%); kawalerowie/panny - 22 (49\%); w związku konkubenckim 1 osoba (2\%).

6. Stan wzroku w oku prawym: (a) ogólna sprawność ruchowa - poczucie inności u badanych z całkowitym niewidzeniem 12 osób (26\%); z poczuciem światła - brak poczucia inności u 1 osoby (2\%); z więcej niż poczuciem światła - u 17 osób (38\%); (b) szybkość i precyzja ruchów - z całkowitym niewidzeniem - 12 osób (26\%); z poczuciem światła - brak poczucia inności u 1 osoby (2\%); z więcej niż poczucie światła - 18 osób (40\%); (c) koordynacja ruchowa - z całkowitym niewidzeniem - $12(26 \%)$; z poczuciem światła 1 osoba $(2 \%)$ z brakiem poczucia inności; z więcej niż poczucie światła - 17 osób (38\%); (d) sprawność manualna - z całkowitym niewidzeniem - 11 (25\%); z poczuciem światła - 1 osoba $(2 \%)$ z brakiem poczucia inności; z więcej niż poczucie światła - 21 osób (47\%).

7. Stan wzroku w oku lewym: (a) ogólna sprawność ruchowa - poczucie inności u badanych z całkowitym niewidzeniem - 9 (20\%); z poczuciem światła - 1 osoba $(2 \%)$ z brakiem poczucia inności; z więcej niż poczucie światła - 20 (44\%); (b) szybkość i precyzja ruchów z całkowitym niewidzeniem - 9 (20\%); z poczuciem światła - $1(2 \%)$ z brakiem poczucia inności; z więcej niż poczucie światła - 21 (47\%); (c) koordynacja ruchowa - z całkowitym niewidzeniem - 9 (20\%); $\mathrm{z}$ poczuciem światła $-1(2 \%) \mathrm{z}$ brakiem poczucia inności; z więcej niż poczucie światła - 20 (44\%); (d) sprawność manualna - z całkowitym niewidzeniem - 9 (20\%); z poczuciem światła - 1 osoba $(2 \%)$ z brakiem poczucia inności; z więcej niż poczucie światła - 23 (51\%).

8. Dodatkowe niepełnosprawności: (a) ogólna sprawność ruchowa - poczucie inności u badanych z brakiem dodatkowych niepełnosprawności - 23 (51\%); u badanych z obecnymi dodatkowymi niepełnosprawnościami - 6 (13\%); (b) szybkość i precyzja ruchów poczucie inności u badanych $\mathrm{z}$ brakiem dodatkowych niepełnosprawności - 23 (51\%); u badanych z obecnymi dodatkowymi nie- 
pełnosprawnościami - 6 (13\%); (c) koordynacja ruchowa - identycznie jak wyżej - poczucie inności u badanych z brakiem dodatkowych niepełnosprawności - 23 (51\%); u badanych z obecnymi dodatkowymi niepełnosprawnościami - 6 (13\%); (d) sprawność manualna - poczucie inności u badanych $\mathrm{z}$ brakiem dodatkowych niepełnosprawności - 26 (58\%); u badanych z obecnymi dodatkowymi niepełnosprawnościami - $6(13 \%)$.

9. Inne ograniczenia związane ze stanem zdrowia: (a) ogólna sprawność ruchowa - poczucie inności $u$ badanych $z$ brakiem dodatkowych ograniczeń zdrowotnych - 23 (51\%); u badanych z obecnymi dodatkowymi ograniczeniami zdrowia - 6 (13\%); (b) szybkość i precyzja ruchów - poczucie inności u badanych z brakiem dodatkowych ograniczeń zdrowotnych - 23 (51\%); u badanych z obecnymi dodatkowymi ograniczeniami zdrowia - 6 (13\%); (c) koordynacja ruchowa - poczucie inności u badanych $\mathrm{z}$ brakiem dodatkowych ograniczeń zdrowotnych - 18 (40\%); u badanych z obecnymi dodatkowymi problemami zdrowotnymi - 11 (25\%); (d) sprawność manualna - poczucie inności u badanych $\mathrm{z}$ brakiem dodatkowych problemów zdrowotnych - 23 (51\%); u badanych z obecnymi dodatkowymi problemami zdrowotnymi - $9(20 \%)$.

10. Stopień niepełnosprawności: (a) ogólna sprawność ruchowa - poczucie inności u badanych z umiarkowanym stopniem niepełnosprawności - 20 (44\%); u badanych znajdujących się w trakcie orzecznictwa - 9 (20\%); (b) szybkość i precyzja ruchów - z umiarkowanym stopniem niepełnosprawności - 22 (49\%); u badanych znajdujących się w trakcie orzecznictwa - 8 (18\%); (c) koordynacja ruchowa $-\mathrm{z}$ umiarkowanym stopniem niepełnosprawności - 21 (47\%); u znajdujących się w trakcie orzecznictwa - 5 (11\%); (d) sprawność manualna - z umiarkowanym stopniem niepełnosprawności 26 (58\%); znajdujący się w trakcie orzecznictwa - 6 (13\%).

11. Okres uszkodzenia wzroku: (a) ogólna sprawność ruchowa - poczucie inności u badanych z uszkodzeniem wzroku od urodzenia - 17 (38\%); od wczesnego dzieciństwa - 4 (9\%); od okresu średniego lub późnego dzieciństwa - 3 (7\%); od okresu młodzieńczego lub dorosłości - 5 (11\%); (b) szybkość i precyzja ruchów - u badanych 
z uszkodzeniem wzroku od urodzenia - 18 (40\%); od wczesnego dzieciństwa - 4 (9\%); od okresu średniego lub późnego dzieciństwa - 3 (7\%); od okresu młodzieńczego lub dorosłości - 5 (11\%); (c) koordynacja ruchowa - z uszkodzeniem wzroku od urodzenia 17 (38\%); od wczesnego dzieciństwa - 4 (9\%) z brakiem poczucia inności; od okresu średniego lub późnego dzieciństwa - 3 (7\%); od okresu młodzieńczego lub dorosłości - 5 (11\%); (d) sprawność manualna - z uszkodzeniem wzroku od urodzenia - 19 (42\%); od wczesnego dzieciństwa - 4 (9\%) z brakiem poczucia inności; od okresu średniego lub późnego dzieciństwa - 4 (9\%); od okresu młodzieńczego lub dorosłości - 5 (11\%).

12. Przyczyna uszkodzenia wzroku: (a) ogólna sprawność ruchowa - poczucie inności u badanych z uszkodzeniem wzroku na tle czynników dziedzicznych - 5 osób (11\%); na tle czynników wrodzonych - 14 (31\%); zaćmy - 1 (2\%) z brakiem poczucia inności; nowotworów oka lub mózgu - 5 (11\%); urazów - 4 (9\%); innych czynników - $1(2 \%)$ z brakiem poczucia inności; (b) szybkość i precyzja ruchów - z uszkodzeniem wzroku na tle czynników dziedzicznych $5(11 \%)$; na tle czynników wrodzonych - 16 (36\%); zaćmy - $1(2 \%)$ z brakiem poczucia inności; nowotworów oka lub mózgu - 5 (11\%); urazów - 4 (9\%); innych czynników - 1 (2\%) z brakiem poczucia inności; (c) koordynacja ruchowa - z uszkodzeniem wzroku na tle czynników dziedzicznych - 5 (11\%); na tle czynników wrodzonych 16 (36\%); zaćmy - 1 (2\%) z brakiem poczucia inności; nowotworów oka lub mózgu - 5 (11\%); urazów - 4 (9\%); innych czynników $1(2 \%)$ z brakiem poczucia inności; (d) sprawność manualna z uszkodzeniem wzroku na tle czynników dziedzicznych - $8(18 \%)$; na tle czynników wrodzonych - 18 (40\%); zaćmy - $1(2 \%)$ z brakiem poczucia inności; nowotworów oka lub mózgu - 2 (4\%); urazów 4 (9\%); innych czynników - 1 (2\%) z brakiem poczucia inności.

13. Aktywność edukacyjna i/lub zawodowa: (a) ogólna sprawność ruchowa - poczucie inności u badanych pracujących i równocześnie uczących się - 4 osoby (9\%); pracujących i nie uczących się 2 (4\%); nie pracujących i nie uczących się - 14 (31\%); uczących się (szkoła gimnazjalna, średnia, policealna) - 7 (15\%); studiujących 
- 2 (4\%); (b) szybkość i precyzja ruchów u badanych pracujących i równocześnie uczących się - 4 (9\%); pracujących i nie uczących się - 2 (4\%); nie pracujących i nie uczących się - 14 (31\%); uczących się (szkoła gimnazjalna, średnia, policealna) - 7 (15\%); studiujących $3(7 \%)$; (c) koordynacja ruchowa u badanych pracujących i równocześnie uczących się - 4 (9\%); pracujących i nie uczących się 2 (4\%); nie pracujących i nie uczących się - 14 (31\%); uczących się (szkoła gimnazjalna, średnia, policealna) - 7 (15\%); studiujących 2 (4\%); (d) sprawność manualna u badanych pracujących i równocześnie uczących się - 4 (9\%); pracujących i nie uczących się - 2 (4\%); nie pracujących i nie uczących się - 12 (26\%); uczących się (szkoła gimnazjalna, średnia, policealna) - 9 (20\%); studiujących - $5(11 \%)$.

14. Typ realizowanej/zrealizowanej edukacji: (a) ogólna sprawność ruchowa - poczucie inności u badanych edukujących się wyłącznie w szkole ogólnodostępnej - 16 (36\%); wyłącznie w szkole specjalnej - 2 (4\%); wyłącznie w szkole integracyjnej - $2(4 \%)$; w szkole ogólnodostępnej, a zatem specjalnej - 3 (7\%); w szkole integracyjnej, a kolejno specjalnej - 1 (2\%); w szkole specjalnej, a następnie ogólnodostępnej - 1 (2\%); (b) szybkość i precyzja ruchów u badanych edukujących się wyłącznie w szkole ogólnodostępnej 17 (38\%); wyłącznie w szkole specjalnej - 2 (4\%); wyłącznie w szkole integracyjnej - 3 (7\%); w szkole ogólnodostępnej, a zatem specjalnej $6(13 \%)$; w szkole integracyjnej, a następnie specjalnej - 1 (2\%); w szkole specjalnej, a kolejno ogólnodostępnej - 1 (2\%); (c) koordynacja ruchowa u badanych edukujących się wyłącznie w szkole ogólnodostępnej - 16 (36\%); wyłącznie w szkole specjalnej - 2 (4\%); wyłącznie w szkole integracyjnej - $3(7 \%)$; w szkole ogólnodostępnej, a kolejno specjalnej - 6 (13\%); w szkole integracyjnej, a następnie specjalnej - 1 (2\%); w szkole specjalnej, a zatem ogólnodostępnej 1 (2\%); (d) sprawność manualna u badanych edukujących się wyłącznie w szkole ogólnodostępnej - 20 (44\%); wyłącznie w szkole specjalnej - 2 (4\%); wyłącznie w szkole integracyjnej - 3 (7\%); w szkole ogólnodostępnej, a zatem specjalnej - 6 (13\%); w szkole integracyjnej, a następnie specjalnej - 1 (2\%); w szkole specjalnej, a kolejno ogólnodostępnej - 1 osoba (2\%) z brakiem poczucia inności. 
15. Akceptacja niepełnosprawności w rodzinie: (a) ogólna sprawność ruchowa - poczucie inności u badanych mających akceptację swojej niepełnosprawności w rodzinie - 24 osoby (53\%); nie mających akceptacji swojej niepełnosprawności w rodzinie - 5 osób (11\%); (b) szybkość i precyzja ruchów u mających akceptację swojej niepełnosprawności w rodzinie - 18 osób (40\%); nie mających akceptacji swojej niepełnosprawności w rodzinie - 12 (26\%); (c) koordynacja ruchowa u mających akceptację swojej niepełnosprawności w rodzinie - 24 osoby (53\%); nie mających akceptacji swojej niepełnosprawności w rodzinie - 5 (11\%); (d) sprawność manualna u mających akceptację swojej niepełnosprawności w rodzinie - 27 osób (60\%); nie mających akceptacji swojej niepełnosprawności w rodzinie - 5 (11\%).

16. Akceptacja niepełnosprawności własna: (a) ogólna sprawność ruchowa - poczucie inności u badanych akceptujących swoją niepełnosprawność - 17 osób (38\%); u nie akceptujących swojej niepełnosprawności - 12 (26\%); (b) szybkość i precyzja ruchów u akceptujących swoją niepełnosprawność - 18 osób (40\%); u nie akceptujących swojej niepełnosprawności - 12 (26\%); (c) koordynacja ruchowa u akceptujących swoją niepełnosprawność - 17 osób (38\%); u nie akceptujących swojej niepełnosprawności - 12 (26\%); (d) sprawność manualna $u$ akceptujących swoją niepełnosprawność - 20 osób (44\%); u nie akceptujących swojej niepełnosprawności - 12 (26\%).

17. Preferowane formy doskonalenia zawodowego: (a) ogólna sprawność ruchowa - poczucie inności u badanych preferujących szkolenie komputerowe - 19 osób (42\%); szkolenie z obsługi biura i recepcji - 17 (38\%); szkolenie z masażu kamieniami - 1 osoba (2\%); (b) szybkość i precyzja ruchów u preferujących szkolenie komputerowe - 19 osób (42\%); szkolenie z obsługi biura i recepcji - 17 (38\%); szkolenie z masażu kamieniami - 1 osoba (2\%); (c) koordynacja ruchowa u preferujących szkolenie komputerowe - 18 osób (40\%); szkolenie z obsługi biura i recepcji - 17 (38\%); szkolenie z masażu kamieniami - 1 osoba (2\%).

18. Dodatkowe potrzeby rehabilitacyjne: (a) ogólna sprawność ruchowa - poczucie inności u badanych wymagających dodatkowych zajęć specjalistycznych z czynności dnia codziennego - 7 osób 
(15\%); z technik komunikacji - także 7 (15\%); z usprawniania widzenia oraz doboru pomocy optycznych i nieoptycznych - 4 osoby $(9 \%)$; z orientacji przestrzennej i przemieszczania się $\mathrm{w}$ przestrzeni 12 (26\%); z rehabilitacji psychologicznej - 11 osób (25\%); z budowania własnego wizerunku - 7 (15\%); innych (konsultacja tyflopedagogiczna) - 1 osoba (2\%); (b) szybkość i precyzja ruchów u wymagających dodatkowych zajęć specjalistycznych z czynności dnia codziennego - 7 osób (15\%); z technik komunikacji - również 7 (15\%); z usprawniania widzenia oraz doboru pomocy optycznych i nieoptycznych - 4 (9\%); z orientacji przestrzennej i przemieszczania się w przestrzeni -12 osób (26\%); z rehabilitacji psychologicznej - 11 (25\%); z budowania własnego wizerunku - 7 (15\%); innych (konsultacja tyflopedagogiczna) - 1 osoba $(2 \%)$; (c) koordynacja ruchowa u wymagających dodatkowych zajęć specjalistycznych z czynności dnia codziennego - 7 osób (15\%); z technik komunikacji - też 7 (15\%); z usprawniania widzenia oraz doboru pomocy optycznych i nieoptycznych -4 osoby (9\%); z orientacji przestrzennej i przemieszczania się $\mathrm{w}$ przestrzeni - $12(26 \%)$; z rehabilitacji psychologicznej - 11 (25\%); z budowania własnego wizerunku 7 (15\%); innych (konsultacja tyflopedagogiczna) - 1 osoba (2\%); (d) sprawność manualna u wymagających dodatkowych zajęć specjalistycznych z czynności dnia codziennego - 7 osób (15\%); z technik komunikacji - 7 (15\%); z usprawniania widzenia oraz doboru pomocy optycznych i nieoptycznych - 4 osoby (9\%); z orientacji przestrzennej i przemieszczania się w przestrzeni $-12(26 \%)$; z rehabilitacji psychologicznej - 11 (25\%); z budowania własnego wizerunku $7(15 \%)$; innych (konsultacja tyflopedagogiczna) - 1 osoba $(2 \%)$.

\section{Wybrane wnioski ogólne}

Na podstawie podanych danych można zasygnalizować wybrane wnioski ogólne związane z obecnością poczucia inności u osób niewidomych i osób z resztkami wzroku: 
1. Zasadniczo głębokość uszkodzenia wzroku nie jest czynnikiem determinującym nasilenie poczucia inności wśród osób badanej populacji i w badanych sferach funkcjonowania. Podobnie wygląda sytuacja z kwestią czynników, które do uszkodzenia wzroku doprowadziły. Natomiast okres uszkodzenia wzroku należy uznać za ważny element współdecydujący o obecności i nasileniu poczucia inności - w większym stopniu poczucie inności obecne jest u osób, które straciły sprawność wzrokową w późniejszym okresie życia.

2. Miejsce zamieszkania - miasto lub wieś - nie wpływa na poczucie inności w analizowanej grupie osób niepełnosprawnych.

3. Na obecność poczucia inności u osób niewidomych i osób z resztkami wzroku w ocenianych obszarach funkcjonowania wpływa ich płeć oraz sytuacja rodzinna. Na obecność poczucia inności bardziej narażone są kobiety (wynika to zapewne z pełnionych przez nie ról społecznych) oraz osoby bez rodziny własnej - kawalerowie/panny (dostrzegalny jest tu wpływ rodziny, szczególnie rodziców oraz ich nadopiekuńczości na obecność poczucia inności).

4. Akceptacja niepełnosprawności wzrokowej przez rodzinę osoby niepełnosprawnej jest ważnym, ale nie zasadniczym determinantem minimalizacji poczucia inności. Istotniejszy jest fakt akceptowania swojej niepełnosprawności przez osobę niewidomą i osobę z resztkami wzroku - nasilone poczucie inności obecne było u osób mających akceptację niepełnosprawności w rodzinie, ale nie akceptujących swojej niepełnosprawności.

5. Typ szkoły, do której uczęszcza lub uczęszczała osoba niewidoma i osoba $\mathrm{z}$ resztkami wzroku, rzutuje na istnienie poczucia inności w obszarze funkcjonowania psychicznego, emocjonalnego i fizycznego. Obserwuje się nasilenie poczucia inności u osób, które edukowały/edukują się w pełni lub częściowo, to znaczy przez pewien okres, w systemie szkolnictwa ogólnodostępnego lub integracyjnego.

6. Osoby niewidome i osoby z resztkami wzroku ze znacznym nasileniem poczucia inności wymagają dodatkowych zajęć z zakresu czynności dnia codziennego, orientacji i przemieszczania się 
w przestrzeni, psychologicznych, z kształtowania własnego wizerunku. Preferują też takie formy szkolenia zawodowego, które dają możliwość pracy niewymagającej nasilonych kontaktów z innymi ludźmi, na przykład szkolenie komputerowe.

\section{Zakończenie}

Powyższe wnioski skłaniają do intensyfikacji działań specjalistycznych na rzecz modyfikacji i dostosowania strategii aktywizacyjnych realizowanych na rzecz osób niewidomych i osób z resztami wzroku, dostosowanych do ich osobistych potrzeb, możliwości psychofizycznych i emocjonalno-społecznych, jak również doświadczanych problemów funkcjonalnych - na każdym poziomie edukacji (z diagnostyką, rehabilitacją specjalistyczną i preorientacją edukacyjno-zawodową włącznie), a także warunków organizacyjnych prowadzonej edukacji i rehabilitacji. Ważnym jest również skierowanie działań specjalistycznych na te obszary funkcjonowania, które powodują szczególne problemy: orientacja i przemieszczanie się w przestrzeni, czynności życia codziennego, kwestie psychiczne i te formy rehabilitacji, które pozwalają na ich niwelację. Istotne jest też uwzględnienie $\mathrm{w}$ procesie edukacyjno-rehabilitacyjnym dostosowanej do wymogów współczesności nomenklatury zawodów, które umożliwiają osobie niewidomej i osobie z resztkami wzroku uzyskanie satysfakcjonującego zatrudnienia, a jednocześnie korelują z jej indywidualnymi preferencjami i zasobami wewnętrznymi.

\section{Bibliografia}

ZAORSKA M., Wsparcie osób niewidomych na rynku pracy - refleksje z realizacji pierwszego etapu, [w:] D. Baczała, J.J. Błeszyński, M. Zaorska (red.), Osoba z niepetnosprawnościa - opieka-terapia-wsparcie, Wyd. UMK, Toruń 2009, s. 359-406.

Źródła z Internetu

<www.pzn.org.pl, 28.07.2010>. 